\title{
DAYA ANTIOKSIDAN EKSTRAK DAN \\ FRAKSI DAUN KOPI ROBUSTA (Coffea robusta) TERHADAP PEREAKSI DPPH (2,2-difenil-1-pikrilhidrazil)
}

\author{
Mauizatul Hasanah', Bella Maharani' ${ }^{1}$, Ensiwi Munarsih ${ }^{1}$ \\ ${ }^{1}$ Sekolah Tinggi Ilmu Farmasi Bhakti Pertiwi, Sumatera Selatan, Indonesia
}

\begin{abstract}
ABSTRAK
Radikal bebas memiliki efek menyebabkan terjadinya kerusakan sel dalam tubuh sebagai pemicu berbagai penyakit. Antioksidan diketahui memiliki kemampuan untuk meredam radikal bebas. Telah dilakukan penelitian potensi aktivitas antioksidan dari ekstrak kental dan fraksi daun kopi robusta (Coffea robusta). Ekstraksi dilakukan dengan metode maserasi menggunakan etanol $70 \%$ selama $3 \times 5$ hari pada suhu ruangan, diperoleh ekstrak kental dengan rendemen $15,9 \% \mathrm{~b} / \mathrm{b}$. Fraksinasi dilakukan dengan pelarut berdasarkan perbedaan kepolaran diperoleh fraksi n-heksan, fraksi etil asetat dan fraksi air. Uji antioksidan menggunakan alat Spektrofotometer Uv-Vis dengan metode penghambatan radikal bebas DPPH (2,2-Difenil-1Pikrilhidrazil) terhadap ekstrak kental dan fraksi n-heksan, etil asetat dan air pada beberapa konsentrasi, yaitu 100 ppm, 80 ppm, 60 ppm, 40 ppm, 20 ppm. Hasil penelitian menunjukkan penghambatan radikal bebas (\% Inhibisi) ekstrak dan fraksi meningkat sesuai peningkatan konsentrasi uji. Nilai \% Inhibisi ekstrak kental, fraksi n-heksan, fraksi etil asetat dan fraksi air, pada konsentrasi 100 ppm berturut-turut adalah 93,7 \%, 95,56\%, 69,54\% dan 61,28\%. Hasil perhitungan $\mathrm{IC}_{50}$ yang diperoleh untuk ekstrak kental adalah $43,83 \mathrm{ppm}$, fraksi n-heksan adalah 38,32 ppm, fraksi etil asetat adalah 37,07 ppm dan fraksi air adalah 73,62 ppm.
\end{abstract}

Kata kunci: Antioksidan, daun kopi (Coffea robusta), DPPH (2,2-Difenil-1 Pikrilhidrazil), ekstraksi, fraksinasi

\section{ANTIOXIDANT OF EXTRACT AND FRACTION Coffea robusta LEAVES WITH DIPHENYLPICRYLHIDRAZYL (DPPH) METODH}

\begin{abstract}
Free radicals can damaged human body cells, antioxidant can inhibit the effect of free radical. The research was about potential antioxidant activity of extracts and fractions from Coffea robusta leaves. Extraction used maceration method with ethanol $70 \%$ for $3 \times 5$ days at room temperature, yield of extract was $15.9 \%$ w/w. Fractionation based on differences in polarity, there were fraction of $n$ - hexane, ethyl fractions and water fraction,. Antioxidant test used a UvVis Spectrophotometer with the method of inhibiting free radical DPPH (2,2-Diphenyl-1picrylhidrazyl) to extract and fractions n-hexane, ethyl acetate and water at some concentration, 100 ppm, 80 ppm, 60 ppm, 40 ppm, and 20 ppm. The inhibition of free radicals (\% ihibition) extract and fractions increased by a corresponding increase in concentration of the test. \% inhibition value at $100 \mathrm{ppm}$ for extract, fraction of $\mathrm{n}$ - hexane, fraction of ethyl acetate and the water fraction respectively were $93.7 \%, 95.56 \%, 69.54 \%$ and $61.28 \%, . \mathrm{IC}_{50}$ of extract total was $43.83 \mathrm{ppm}$, fraction of $\mathrm{n}$ - hexane was $38.32 \mathrm{ppm}$, ethyl acetate was $37.07 \mathrm{ppm}$ and water fraction was $73.62 \mathrm{ppm}$.
\end{abstract}

Keywords : Antioxidant, leaf coffee (Coffea robusta), DPPH (2,2-Diphenyl-1 picrylhidrazyl), extraction, fractionation 


\section{Pendahuluan}

Radikal bebas bersumber dari bahan bahan kimia yang berasal dari penggunaan pestisida, polusi udara, asap rokok, alkohol, bahkan dari penggunaan bahan kimia sintesis pada obat dan pangan, dapat memicu timbulnya berbagai penyakit. Antioksidan berfungsi untuk mencegah pengaruh radikal bebas yang menyebabkan terjadinya stress oksidatif pemicu penyakit. Antioksidan bisa diperoleh dari bahan bahan alam dan dimanfaatkan sebagai obat herbal mengandung antioksidan. ${ }^{1}$

Sel tubuh dapat mengalami kerusakan yang diakibatkan oleh proses oksidasi senyawa kimia yang menghasilkan radikal bebas yang memulai terjadinya beberapa rantai reaksi yang bisa merusak sel tubuh tersebut. Antioksidan berperan menyingkirkan radikal bebas melalui reaksi, dan menghambat terjadinya reaksi oksidasi lain. Antioksidan yang banyak digunakan adalah antioksidan sintetik, dan ditambah dengan pemanfaatan bahan alami sebagai antioksidan. ${ }^{2}$

Daun kopi telah digunakan secara alami dan tradisional dalam berbagai pengobatan. Sejumlah sifat kesehatan yang menguntungkan telah dikaitkan dengan kopi, antara lain adalah diuretik, antimikroba dan aktivitas antioksidan. Daun kopi robusta (Coffea robusta) memiliki kandungan alkaloid, senyawa fenolik, karbohidrat, protein dan saponin, dengan kadar kandungan fenolik total sebesar 27,04 $\mu \mathrm{g} / \mathrm{g}$ dan flavonoid sebesar $10,90 \mu \mathrm{g} / \mathrm{g}$. Aktivitas antioksidan ekstrak daun kopi robusta (Coffea robusta) berupa daya hambat radikal bebas 1,1 Diphenyl-2pikrilhidrazil pada konsentrasi terkecil, yaitu $10 \mathrm{ppm}$ menunjukkan daya hambat sebesar $79,43 \% .^{3}$

\section{Metode}

Alat yang digunakan adalah seperangkat alat maserasi, destilasi vakum, rotary evaporator, pipet mikron $0,2 \mathrm{ml}$ (Socorex), alat - alat gelas labor kimia,
Spektrofotometri UV-VIS ( Shimidzu UVPharmaspec 1700 ).

Bahan yang digunakan untuk penelitian ini adalah Daun Kopi (Coffea Robusta), Pereaksi 2,2-Difenil-1-Pikrilhidrazil; DPPH (Sygma Aldrich), Etanol Absolute (Merck), Aquadest, Metanol PA (Merck), Etil Asetat 99,5\% (Merck), N-Heksan 90\% (Merck), Vitamin C, Kloroform, Kloroform Amoniak, Asam Sulfat 2N, Pereaksi Mayer, logam $\mathrm{Mg}$, Hcl Pekat, $\mathrm{FeCl}_{3}, \mathrm{CHCl}_{3}$, Norit, Asam Asetat Anhidrat $10 \%, \mathrm{H}_{2} \mathrm{SO}_{4}$ pekat, dan pasir bersih, kertas saring, kapas.

Ekstraksi dilakukan dengan menggunakan metode maserasi atau perendaman sampel menggunakan pelarut, kemudian dilanjutkan dengan fraksinasi berdasarkan kepolaran pelarut (non-polar, semi-polar dan polar).

Pengujian aktivitas antioksidan dilakukan dengan menggunakan metode DPPH (2,2-Difenill-1-Pikrilhidrazil) yang direaksikan dengan senyawa antioksidan yang terdapat pada sampel dan pembanding Vitamin C. Aktivitas antioksidan ditentukan berdasarkan nilai \% Inhibisi dan nilai $\mathrm{IC}_{50}{ }^{4}$

Sampel penelitian adalah daun kopi robusta (Coffea robusta) yang diperoleh dari daerah Pagar Alam, Sumatera Selatan dan identifikasi tumbuhan uji dilakukan di Herbarium Universitas Andalas Padang, Sumatra Barat. Sampel yang digunakan adalah daun kopi robusta (Coffea robusta) berwarna hijau tua, diambil, dikumpulkan dan disimpan di dalam wadah penyimpanan dan dibawa ke laboratorium untuk diteliti.

Daun kopi (Coffea robusta), disortir, dibersihkan terlebih dahulu kemudian dikering anginkan. Sampel kering diserbukkan dengan diblender, ditimbang sebanyak $250 \mathrm{~g}$.

Sampel serbuk kering daun kopi robusta (Coffea robusta) sebanyak $250 \mathrm{~g}$, diekstraksi dengan metode maserasi yaitu dengan dimasukkan ke dalam maserator, ditambahkan pelarut etanol $70 \%$ hingga terendam semua. Alat ditutup rapat dan disimpan di tempat yang terlindung dari 
cahaya matahari sambil sesekali dikocok, dibiarkan selama 5 hari, disaring menghasilkan maserat dan ampas. Ampas yang didapat dimaserasi kembali dengan pelarut yang sama, proses dilakukan sebanyak 3 x 5 hari, kemudian maserat yang dihasilkan dikumpulkan dalam satu wadah.

Maserat diuapkan pelarutnya dengan destilasi vakum, diperoleh ekstrak cair. Ekstrak cair dipekatkan, digunakan rotary evaporator, diperoleh ekstrak kental untuk difraksinasi.

Fraksinasi dilakukan dengan cara ekstrak kental dilarutkan dengan $200 \mathrm{ml}$ air di dalam beaker gelas dan diaduk sampai larut. Dipindahkan ke dalam corong pisah $500 \mathrm{ml}$ dan dilkukan fraksinasi dengan menggunakan pelarut $\mathrm{n}$ - heksan, didapatkan fraksi n-heksan dan fraksi sisa air. Fraksi sisa air yang diperoleh difraksinasi menggunakan pelarut etil asetat sehingga diperoleh fraksi etil asetat dan fraksi sisa air kembali. Fraksi n- heksan, fraksi etil asetat dan fraksi sisa air kemudian diuapkan menggunakan alat destilasi vakum dan dikentalkan menggunakan Rotary evaporator. Diperoleh fraksi n- heksan, fraksi etil asetat dan fraksi air.

Sampel ekstrak kental, fraksi n-heksan, fraksi etil asetat, dan fraksi air ditimbang masing-masing sebanyak $100 \mathrm{mg}$ kemudian dilarutkan menggunakan $20 \mathrm{ml}$ methanol di dalam beaker gelas. Dimasukkan ke dalam labu ukur $100 \mathrm{ml}$ dicukupkan dengan metanol sampai tanda batas sehingga didapat konsentrasi larutan sampel 1000 ppm.

Larutan uji berbagai konsentrasi dibuat dengan dipipet dari larutan induk 1000 ppm sebanyak $5 \mathrm{ml}, 4 \mathrm{ml}, 3 \mathrm{ml}, 2 \mathrm{ml}, 1 \mathrm{ml}$ dimasukkan ke dalam labu ukur $50 \mathrm{ml}$ dicukupkan dengan metanol sampai tanda batas, didapat larutan uji seri konsentrasi 100 ppm, 80 ppm, 60 ppm, 40 ppm, dan 20 ppm.

Larutan pembanding Vitamin $\mathrm{C}$, dibuat dengan ditimbang sebanyak $50 \mathrm{mg}$ Vitamin $\mathrm{C}$ dimasukkan ke dalam labu ukur $50 \mathrm{ml}$ ditambahkan metanol $10 \mathrm{ml}$ dikocok hingga homogen dicukupkan dengan metanol sampai tanda batas, sehingga didapat konsentrasi larutan vitamin C 1000 ppm. Lalu dibuat larutan uji pembanding dengan konsentrasi 25 ppm, 20 ppm, 15 ppm, 10 ppm, 5 ppm dengan dipipet sebanyak 1,25 $\mathrm{ml}, 1 \mathrm{ml}, 0,75 \mathrm{ml}, 0,5 \mathrm{ml}$, dan $0,25 \mathrm{ml}$ dari larutan induk dimasukkan ke dalam labu ukur $50 \mathrm{ml}$ ditambahkan metanol sampai tanda batas.

Untuk uji antioksidan, dipipet masingmasing 0,2 ml larutan uji sampel berbagai konsentrasi (sampel uji ekstrak kental, fraksi n-heksan, fraksi etil asetat dan fraksi air) dan larutan pembanding berbagai konsentrasi dimasukkan ke dalam vial.

DPPH ditimbang sebanyak $5 \mathrm{mg}$ dimasukkan ke dalam labu ukur $250 \mathrm{ml}$ ditambahkan metanol hingga tanda batas dikocok homogen, sehingga diperoleh larutan DPPH dengan konsentrasi 0,05 mM.

Larutan DPPH 0,05 mM sebanyak 3,8 $\mathrm{ml}$, ditambahkan dengan $0,2 \mathrm{ml}$ metanol. Dibiarkan selama 30 menit ditempat gelap yang terlindung dari cahaya, diukur serapan dengan Spektrofotometer UV-Vis pada panjang gelombang dengan rentang 515 $520 \mathrm{~nm}$ hingga diperoleh panjang gelombang maksimum.

Ditentukan terlebih dahulu absorbansi DPPH sebagai kontrol secara berurutan untuk masing-masing sampel uji dan pembanding sebelum direaksikan, yaitu dengan dipipet 0,2 metanol dan ditambahkan DPPH 0,05mM sebanyak 3,8 $\mathrm{ml}$ dibiarkan selama 30 menit dan diukur absorbansinya.

Pengukuran absorbansi DPPH yang direaksikan dengan larutan uji sampel dan pembanding dilakukan dengan dipipet 0,2 ml larutan uji (sampel uji ekstrak kental, fraksi n-heksan, fraksi etil asetat, fraksi air) dan larutan pembanding yang telah disiapkan, secara berurutan masing-masing ditambahkan dengan 3,8 ml larutan DPPH 0,05 $\mathrm{mM}$ dan dibiarkan selama 30 menit ditempat gelap yang terlindung dari cahaya.

Absorbansi diukur dengan Spektrofotometer UV-VIS pada panjang gelombang serapan maksimum DPPH. Pengujian aktivitas antioksidan dilakukan 
sebanyak tiga kali pengulangan untuk masing-masing konsentrasi larutan uji dan larutan pembanding secara berurutan.

Aktivitas antioksidan sampel ditentukan oleh besarnya hambatan serapan radikal DPPH melalui perhitungan persentase inhibisi serapan DPPH dengan menggunakan rumus :

$$
\% \text { Inhibisi }=\frac{A_{\text {awal }}-A_{\text {setelah reaksi }}}{A_{\text {setelah reaksi }}} \times
$$

Keterangan:

$\mathrm{A}_{\mathrm{awal}}=$ Absorbansi DPPH kontrol pada $\lambda$ maksimum sebelum direaksikan dengan larutan uji.

$\mathrm{A}_{\text {setelah reaksi }}=$ Absorbansi $\mathrm{DPPH}$ pada $\lambda$ maksimum setelah direaksikan dengan larutan sampel uji dan pembanding.

Nilai $\mathrm{IC}_{50}$ diperoleh dengan terlebih dahulu membuat persamaan garis yang menghubungkan antara \% Inhibisi terhadap konsentrasi larutan uji masing-masing sampel (100 ppm, 80 ppm, 60 ppm, 40 ppm, $20 \mathrm{ppm}$ ) dan pembanding Vitamin C (25 ppm, 20 ppm, 15 ppm, 10 ppm dan 5 ppm).

$\mathrm{IC}_{50}$ diperoleh dengan menghitung konsentrasi larutan uji yang bisa menghasilkan hambatan radikal bebas (\% inhibisi) sebesar 50 berdasarkan persamaan garis regresi linear korelasi I dengan K menggunakan rumus :

Keterangan :

$$
y=a x+b
$$

$$
\begin{aligned}
& y=50 \\
& x=\text { Konsentrasi larutan uji (K) }
\end{aligned}
$$

Data yang diperoleh dari alat Spektrofotometri UV-Vis berupa absorbansi DPPH kontrol dan DPPH setelah direaksikan dengan larutan uji sampel dan pembanding pada berbagai konsentrasi, digunakan untuk menghitung $\%$ Inhibisi. \% Inhibisi digunakan untuk memperoleh $\mathrm{IC}_{50}$. Penyajian data dalam bentuk tabulasi, hasil dianalisis dengan membandingkan nilai $\mathrm{IC}_{50}$ yang didapatkan dari pengujian antioksidan terhadap ekstrak kental, fraksi n-heksan, fraksi etil asetat, dan fraksi air. Analisis juga dilakukan dengan statistik menggunakan uji analisis varians satu arah (ANOVA one-way) dilanjutkan dengan uji duncan. ${ }^{4}$

\section{Hasil}

Sebanyak 250 gram serbuk daun kopi robusta menghasilkan ekstrak kental 39,76 gram diperoleh rendemen $15,9 \%(\mathrm{~b} / \mathrm{b})$

Hasil fraksinasi menggunakan pelarut n-heksan, etil asetat dan air menghasilkan fraksi n-heksan dengan rendemen 25,71 $\%(\mathrm{~b} / \mathrm{b})$, fraksi etil asetat dengan rendemen 28,68 \%(b/b) dan fraksi air dengan rendemen $36,59 \%(\mathrm{~b} / \mathrm{b})$.

Hasil penapisan fitokimia diperoleh hasil pada Tabel 1 .

Hasil perhitungan $\%$ Inhibisi pembanding vitamin $\mathrm{C}$ pada konsentrasi 25 ppm, 20 ppm, 15 ppm, 10 ppm, dan 5 ppm berturut-turut adalah $62,75 \%, 57,61 \%$, $42,20 \%, 38,53 \%$ dan $26,05 \%$.

Hasil perhitungan $\mathrm{IC}_{50}$, Nilai IC50 dari ekstrak kental daun kopi (Coffea robusta), fraksi n-heksan, fraksi etil asetat, fraksi air dan vitamin $\mathrm{C}$ berdasarkan persamaan grafik hubungan antara konsentrasi terhadap \% Inhibisi terdapat pada Tabel 3. Hasil uji statistik analisis varians satu arah (ANOVA one-way) menunjukkan bahwa nilai $\mathrm{IC}_{50}$ pada fraksi air, fraksi n-heksan dan fraksi etil asetat memiliki perbedaan yang difraksinasi menggunakan pelarut berdasar tingkat kepolaran yang berbeda memiliki nilai $\mathrm{IC}_{50}$ yang berbeda signifikan dengan nilai $\mathrm{p}<0,05$. Hasil analisis Duncan juga menunjukkan perbedaan yang nyata pada data $\mathrm{IC}_{50}$ antar fraksi yang berbeda.

Panjang gelombang DPPH diperoleh 516,8 nm dengan absorban 0,540 .

Hasil perhitungan \% Inhibisi sampel uji dan pembanding terdapat pada Tabel 2 . 
Tabel 1 Penapisan Fitokimia

\begin{tabular}{lcccccc}
\hline \multicolumn{1}{c}{ Sampel } & Alkaloid & Flavonoid & Fenolik & Saponin & Terpenoid & Steroid \\
\hline Sampel Segar & + & + & + & + & + & - \\
Ekstrak Kental & + & + & + & + & + & - \\
$\begin{array}{l}\text { Fraksi N- } \\
\text { heksan }\end{array}$ & + & - & - & - & + & - \\
$\begin{array}{l}\text { Fraksi Etil } \\
\text { Asetat }\end{array}$ & + & + & + & - & - & - \\
Fraksi Air & - & + & + & - & - & - \\
\hline
\end{tabular}

Keterangan : (+) teridentifikasi, (-) tidak teridentifikasi

Tabel 2 Hasil Perhitungan \% Inhibisi Sampel Uji

\begin{tabular}{ccccc}
\hline $\begin{array}{c}\text { Konsentrasi } \\
(\mathrm{ppm})\end{array}$ & $\begin{array}{c}\text { Ekstrak } \\
\text { Kental } \\
(\%)\end{array}$ & $\begin{array}{c}\text { Fraksi } \\
\text { N-Heksan } \\
(\%)\end{array}$ & $\begin{array}{c}\text { Fraksi Etil } \\
\text { Asetat }(\%)\end{array}$ & $\begin{array}{c}\text { Fraksi Air } \\
(\%)\end{array}$ \\
\hline 100 & 93,7 & 95,56 & 69,54 & 61,28 \\
80 & 74,25 & 82,25 & 65,24 & 54,12 \\
60 & 60,92 & 70,97 & 58,53 & 45,68 \\
40 & 49,81 & 54,89 & 50,27 & 34,67 \\
20 & 31,48 & 31,05 & 44,22 & 18,53 \\
\hline
\end{tabular}

Hasil perhitungan \% Inhibisi pembanding vitamin $\mathrm{C}$ pada konsentrasi 25 ppm, 20 ppm, 15 ppm, 10 ppm, dan 5 ppm berturut-turut adalah $62,75 \%, 57,61 \%$, $42,20 \%, 38,53 \%$ dan $26,05 \%$.

Hasil perhitungan $\mathrm{IC}_{50}$, Nilai IC50 dari ekstrak kental daun kopi (Coffea robusta), fraksi n-heksan, fraksi etil asetat, fraksi air dan vitamin $\mathrm{C}$ berdasarkan persamaan grafik hubungan antara konsentrasi terhadap \% Inhibisi terdapat pada Tabel 3.

Tabel 3 Hasil Nilai IC $_{50}$

\begin{tabular}{lc}
\hline \multicolumn{1}{c}{ Sampel } & $\begin{array}{c}\text { Nilai IC } \\
\text { (ppm) }\end{array}$ \\
\hline Ekstrak kental & 43,83 \\
Fraksi N-Heksan & 38,32 \\
Fraksi Etil Asetat & 37,07 \\
Fraksi Air & 73,62 \\
Vitamin C & 17,47 \\
\hline
\end{tabular}

Hasil uji statistik analisis varians satu arah (ANOVA one-way) menunjukkan bahwa nilai $\mathrm{IC}_{50}$ pada fraksi air, fraksi nheksan dan fraksi etil asetat memiliki perbedaan yang difraksinasi menggunakan pelarut berdasar tingkat kepolaran yang berbeda memiliki nilai $\mathrm{IC}_{50}$ yang berbeda signifikan dengan nilai $\mathrm{p}<0,05$. Hasil analisis Duncan juga menunjukkan perbedaan yang nyata pada data $\mathrm{IC}_{50}$ antar fraksi yang berbeda.

\section{Pembahasan}

Ekstraksi sampel serbuk kering sebanyak 250 gram, rendemen yang di dapatkan adalah $15,9 \%$. Hasil \% rendemen didapatkan dengan perhitungan sebagai berikut:

Rendemen $=\frac{\text { ekstrak kental }}{\text { ekstrak awal }} \times 100 \%$ 
Hasil ekstrak kental daun kopi robusta (Coffea robusta) kemudian difraksinasi. Fraksinasi dilakukan dengan menggunakan pelarut n-heksan (non-polar), etil asetat (semi polar) dan yang tersisa pada pelarut air (polar). Tujuan dari proses fraksinasi adalah untuk memisahkan senyawa kimia berdasarkan tingkat kepolarannya. Hasil fraksinasi dari masing-masing ekstrak kemudian dikentalkan kembali dengan menggunakan alat Rotary evaporator sehingga didapat ekstrak kental dari masing-masing fraksi.

Sampel segar, ekstrak kental, fraksi nheksan, fraksi etil asetat, dan fraksi air daun kopi robusta (Coffea robusta) dilakukan uji pendahuluan terlebih dahulu atau yang sering disebut dengan uji fitokimia. Uji pendahuluan ini dilakukan untuk mengetahui senyawa metabolit sekunder apa saja yang terkandung di dalam tumbuhan tersebut. Hasil pemeriksaan pendahuluan kandungan kimia daun kopi robusta (Coffea robusta) dengan pereaksi kimia menunjukkan bahwa pada sampel segar positif mengandung alkaloid, flavonoid, fenolik, terpenoid, steroid dan saponin.

Pengujian efek antioksidan dengan menggunakan metode DPPH, metode ini digunakan karena prosedur pengukuran aktivitas antioksidan yang sangat mudah dapat dilakukan dalam waktu yang cukup singkat dan menggunakan sampel dalam jumlah yang sedikit, dan pengukuran dengan spektrofotometri Uv-Vis.

Aktivitas antioksidan metode DPPH ditunjukkan oleh hambatan serapan radikal DPPH pada panjang gelombang serapan maksimum 516,8 nm. Pengujian aktivitas antioksidan metode DPPH ini dilakukan setelah dibiarkan selama 30 menit dan dilakukan ditempat gelap karena DPPH (2,2-difenil-1-pikrilhidrazil) sangat peka terhadap cahaya. Aktivitas antioksidan terlihat dari penurunan serapan larutan DPPH akibat adanya penambahan sampel, seperti pada Gambar 1. Apabila DPPH direduksi maka ditunjukkan dengan penurunan warna keunguan menjadi warna kuning karena adanya aktivitas antioksidan. 4

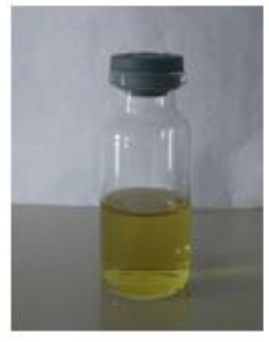

(a)

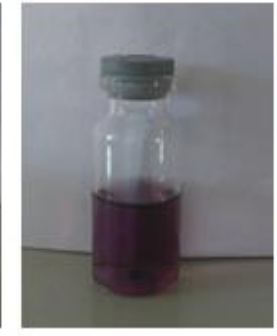

(b)

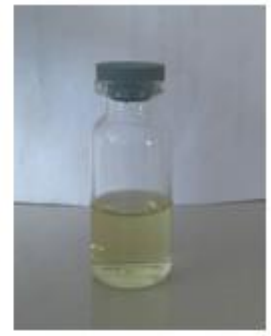

(c)

Gambar 1. Perubahan warna DPPH awal (b) dan sampel (a) sebelum reaksi dan setelah DPPH dan sampel direaksikan (c)

Pengukuran aktivitas antioksidan dari ekstrak total daun kopi robusta (Coffee robusta) ini dibuat bebarapa konsentrasi yaitu 100, 80, 60, 40 dan 20 ppm. Pengujian efek aktivitas antioksidan dari masingmasing fraksi n-heksan, fraksi etil asetat, fraksi air menunjukkan adanya aktivitas antioksidan, pada ekstrak kental dengan konsentrasi 100, 80, 60, 40, dan 20 ppm berturut-turut adalah $93,70 \%, 74,25 \%$, $60,92 \%, 49,81 \%$, dan $31,48 \%$ terhadap fraksi n-heksan pada konsentrasi 100, 80,
60, 40, dan 20 ppm berturut-turut adalah $95,56 \%, 82,25 \%, 70,97 \%, 54,89 \%$ dan $31,05 \%$ terhadap fraksi etil asetat pada konsentrasi 100, 80, 60, 40 dan 20 ppm berturut-turut adalah $69,54 \%, 65,24 \%$, $58,53 \%, 50,27 \%$, dan 44,22 \% terhadap fraksi air pada konsentrasi 100, 80, 60, 40, dan 20 ppm berturut-turut adalah $61,28 \%$, $54,12 \%, 45,68 \%, 34,67 \%$, dan 18,53\%, dengan perbandingan ditampakkan pada Gambar 2. 


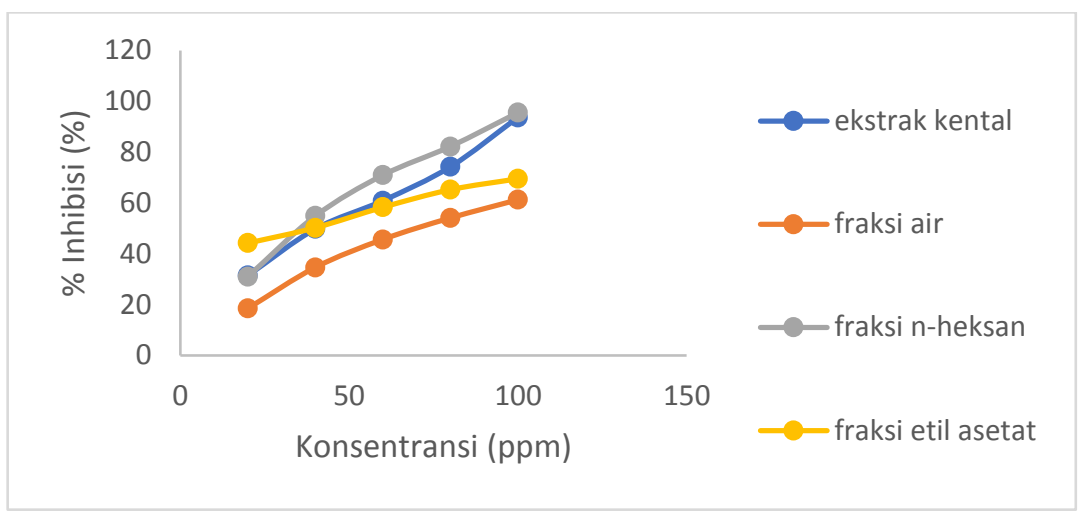

Gambar 2. Kurva hubungan konsentrasi sampel (ppm) dan \% inhibisi berbagai sampel perhitungan pada saat $\%$ inhibisi sebesar 50

Hasil perhitungan persen inhibisi, didapatkan bahwa ekstrak daun kopi robusta pada fraksi etil asetat mempunyai persen inhibisi yang lebih tinggi dibandingkan dengan ekstrak kental, fraksi n-heksan dan fraksi air. Selanjutnya dari perhitungan persen inhibisi masing-masing hasil ekstraksi kemudian dihitung $\mathrm{IC}_{50}$.

Penentukan $\mathrm{IC}_{50}$ dari ekstrak daun kopi robusta hasil ekstraksi secara maserasi dari beberapa fraksi, n-heksan, fraksi etil asetat dan fraksi air dilakukan dengan memasukkan nilai hasil perhitungan ke dalam persamaan linier dengan konsentrasi (ppm) sebagai absis $(X)$ dan nilai persentase inhibisi sebagai ordinat $(\mathrm{Y})$, nilai $\mathrm{IC}_{50}$ dari dengan persamaan $\mathrm{Y}=\mathrm{aX}+\mathrm{b}$.

Nilai IC $_{50}$ ekstrak kental, fraksi nheksan, fraksi etil asetat dan fraksi air berturut-turut 43,83 ppm, 38,32 ppm, 37,07 ppm dan 73,62 ppm, (Tabel 3). Pada penelitian yang dilakukan Cahyani (2015) ekstrak daun kopi robusta (Coffea robusta) memiliki nilai IC $_{50}$ sebesar 17,230 ppm.

Hasil perhitungan $\mathrm{IC}_{50}$ ekstrak total dan ketiga fraksi, fraksi etil asetat mempunyai aktivitas antioksiadn terbaik, dengan nilai $\mathrm{IC}_{50}$ paling rendah dibandingkan, sedangkan pada fraksi air mempunyai antioksidan terendah dengan nilai $\mathrm{IC}_{50}$ tertinggi, seperti pada Gambar 3.

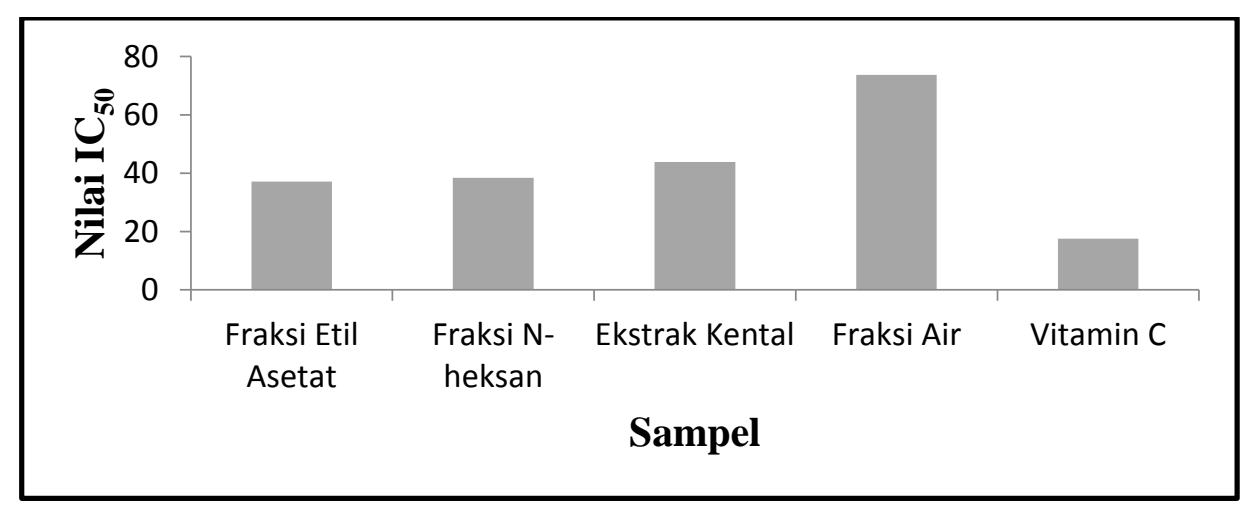

Gambar 3. Nilai $\mathrm{IC}_{50}$

Hasil pemeriksaan aktivitas antioksidan memperoleh data yang menunjukkan bahwa fraksi etil asetat memiliki aktivitas antioksidan yang lebih baik dari ekstrak kental, fraksi n-heksan dan fraksi air. Aktivitas antioksidan berasal dari senyawa fitokimia yang terdapat pada ekstrak dan fraksi dari daun kopi robusta, diantaranya yang diketahui positif berdasarkan uji fitokimia adalah fenolik, alkaloid, saponin, yang memiliki sifat antioksidan. Senyawa flavanoid dan fenolik yang terkandung dalam ekstrak daun kopi robusta dengan gugus hidroksil bebas baru 
mempunyai aktivitas penangkap radikal dan berperan untuk mencegah pembentukan radikal bebas baru dengan cara memutus reaksi berantai dan mengubahnya menjadi produk yang lebih stabil.

Flavonoid berperan pada proses pencegahan dan penyembuhan berbagai penyakit. Sumber flavonoid adalah dari buah - buahan dan sayuran. Berbagai jenis Flavonoid memiliki sifat fisika, kimia dan fisiologis yang berbeda. flavonoid memiliki aktivitas antioksidan, mampu menangkal radikal bebas, serta mengatasi stress oksidatif. ${ }^{5}$

Senyawa saponin memiliki aktivitas antioksidan, diantara senyawa saponin yang beraktivitas antioksidan adalah alphahederin, hederasaponin-C, hederacolchiside-E dan hederacolchiside-F. ${ }^{6}$ Alkaloid, juga memiliki aktivitas sebagai antioksidan yang kuat, salah satunya adalah alkaloid jenis quinolizidine. ${ }^{7}$

\section{Simpulan}

Pengujian aktivitas antioksidan ekstrak daun kopi robusta (Coffee robusta) membuktikan bahwa ekstrak total, fraksi air, fraksi etil asetat dan fraksi n-heksan memiliki aktivitas antioksidan.

Nilai $\mathrm{IC}_{50}$ memiliki perbedaan yang signifikan berdasar uji statistis, dari ekstrak kental, fraksi n-heksan, fraksi etil asetat, fraksi air daun kopi robusta (Coffee robusta) dengan nilai berturut-turut adalah 43,83 ppm, 38,32 ppm, 37,07 ppm dan $73,62 \mathrm{ppm}$.

Intensitas aktivitas antioksidan berturut-turut dari yang teringgi adalah fraksi etil asetat, fraksi $\mathrm{N}$ - heksan dan fraksi air.

\section{Daftar Pustaka}

1. Sen, S., Chakraborty, R., Sridhat, C., Reddy, Y. S. R., and Biplab De. Free radicals, antioxidants, disease and phytomedicines: Current status and future prospect. International Jurnal of Pharmaceutical Sciences Review and Research. 2010; 3(1):92 - 100.

2. Shebis, Y., Iluz, D., Kinel-Tahan, Y., Dubinsky, Z., and Yehoshua, Y. Natural antioxidants: Function and sources. Review. Food and Nutrition Sciences. 2013; 4:643 - 649 .

3. Nayeem, N., Gladsy, D., Shalini, K. M. 2011. Comparative phytochemical analysis, antimicrobial and antioxidant activity of the methanolic extracts of the leaves of coffee Arabica and Coffee Robusta. Der Pharmacia Lettre. 2011; 3(1):292-297.

4. Molyneux, P. The use of the stable free radical diphenylpicrylhydrazyl (DPPH) for estimating antioxidant activity. Songklanakarin J. Sci. Technol. 2003;26: 211-219.

5. Kumar, S. And Pandey, A., K. 2013. Review article, Chemistry and biological activities of flavonoids. The scientific World Journal. 2013. 16 pages.

6. Gulcin, I., Mshvildadze, V., Gepdiremen, A., and Elias, R. Antioxidant activity of saponins isolated from Ivy: alpha-Hederin, Hederasaponin-C, Hederacolchidisde-E and Hederacolchiside-F. Planta Medica. 2004;70(6):561-563.

7. Maiza-Benabdesselam, F., Khentache, S., Bougoffa, K., Chibane, M., Adach, S., Chapeleur, Y., Max, H., and LaurainMattar, D. Antioxidant activities of alkaloid extracts of two Algerian species of Fumaria : Fumaria capreolata and Fumaria bastardii. Rec. Nat. Prod. 2007;1:2-3, 28 - 35 . 